\title{
MODEL PERMAINAN TEMATIK INTEGRATIF UNTUK MENINGKATKAN KEBUGARAN JASMANI, MENGENAL HURUF DAN ANGKA ANAK TK
}

\section{THEMATIC INTEGRATIVE GAME MODELS TO IMPROVE THE PHYSICAL FITNESS, RECOGNIZ LETTERS AND NUMBERS KINDERGARTEN STUDENTS}

\author{
Asriansyah, Suharjana \\ Prodi Ilmu Keolahragaan PPs UNY, Universitas Negeri Yogyakarta \\ asriansyah_syah@yahoo.com, suharjana_fikuny@yahoo.com
}

\begin{abstract}
Abstrak
Penelitian ini bertujuan untuk menghasilkan model permainan bagi anak TK untuk meningkatkan kebugaran jasmani, mengenal huruf, dan angka. Langkah-langkah penelitian dan pengembangan ini adalah: (1) potensi dan masalah, (2) pengumpulan data, (3) desain produk, (4), validasi desain, (5) revisi desain, (6) uji coba produk, (7) revisi produk, (8) uji coba produk, (9) revisi produk, dan (10) produksi masal. Uji coba penelitian dilakukan di TK Aisyiyah Bustanul Athfal Karangmalang, TK Nasional Samirono, dan TK Kartini Karanggayam berjumlah 57 anak. Teknik anlisis data yakni analisis deskriptif kuantitatif dan analisis deskriptif kualitatif. Hasil penelitian ini menghasilkan enam macam model permainan yakni: (1) permainan Kupu-kupu Terbang, (2) permainan Lompat Kelinci, (3) permainan Pesawat Terbang, (4) permainan Lompat Balok, (5) permainan Ular dan Katak, dan (6) permainan Jalan Kepiting. Hasil penilaian para pakar dan praktisi menyimpulkan, model permainan tematik integratif sangat baik digunakan di TK.
\end{abstract}

Kata Kunci: permainan, kebugaran jasmani, huruf, angka

\begin{abstract}
This study aims at producing game models for kindergarten students to increase physical fitness, recognize letters, and numbers. Research and development by following the steps: (1) the potential and problems, (2) data collection, (3) product design, (4), design validation, (5) revision of the design, (6) product trials, (7) the revision of the product, (8) product trials, (9) the revision of the product, and (10) mass production. Research trials conducted in Kindergarten Aisyiyah Bustanul Karangmalang RA, Kindergarten National Samirono, and Kindergarten Kartini Karanggayam totaled 57 children. The data analysis techniques performed were descriptive quantitative and descriptive qualitative. The results of this study produces six kinds of models namely: (1) Flying Butterfly Game, (2) Rabbit Jumping Game, (3) Aircraft Games, (4) Beams Jumping Games, (5) Game of Snakes and Frogs, and (6) Crab Walking Game. The results assessment experts and practitioners conclude, thematic integrative model of the game is very well used in kindergarten.
\end{abstract}

Keywords: games, thematic integrative, physical fitness, letters, numbers 


\section{Pendahuluan}

Anak taman kanak-kanak (TK) merupakan kelompok anak yang berada pada fase anak usia dini (early childhood) dengan rentang usia antara 4-6 tahun. Anak usia dini yang mengikuti pendidikan di taman kanak-kanak merupakan bagian dari pendidikan prasekolah atau sering disebut Pendidikan Anak Usia Dini (PAUD). Pendidikan Anak Usia Dini diselenggarakan sebelum anak mengenyam jenjang pendidikan dasar sebagaimana termaktub dalam Undang-undang Republik Indonesia Nomor 20 Tahun 2003 pasal 28 pasal 1 . Masa anak taman kanak-kanak memiliki karakteristik yang khas, baik secara fisik, psikis, sosial, moral, dan emosional.

Masa kanak-kanak adalah masa-masa yang paling penting untuk pertumbuhan dan perkembangan anak selanjutnya. Masa kanakkanak merupakan awal pembentukkan dari seluruh potensi-potensi yang dimiliki anak seperti aspek perkembangan fisik/motorik, kognitif, sosial/emosional, bahasa, dan nilai-nilai norma/ agama. Potensi-potensi yang dimiliki anak berkembang melalui pengalaman, berupa pengalaman gerak dan pengalaman informasi. Umumnya, pengalaman gerak dan informasi didapatkan di sekolah, masyarakat, dan keluarga, yakni melalui bermain. Pengalaman gerak yang dialami oleh anak akan berpengaruh kuat terhadap kehidupan selanjutnya. Pengalamanpengalaman gerak yang didapatkan anak akan bertahan lama sehingga semua bentuk kegiatan bermain atau belajar anak taman kanak-kanak harus benar-benar diperhatikan.

Pendidikan anak taman kanak-kanak merupakan suatu lembaga pendidikan baik formal maupun nonformal sebagai cikal bakal generasi penerus perjuangan dan pembangunan bangsa. Sebagaimana menurut Elliot \& Davis (2009, p.66) "education has a key role and all sectors-including early childhood educationmust be a part of re-imagining and transforming current unsustainable patterns of living". Maksudnya adalah pendidikan memiliki peran penting dari semua sektor-sektor, termasuk pendidikan anak usia dini yang menjadi bagian dari cita-cita untuk mengubah pola hidup yang tidak dapat bertahan lama. Pendidikan taman kanakkanak merupakan salah satu faktor awal mendukung keadaan negara ke depan, karenanya pemerintah harus mempunyai perhatian secara khusus untuk mengelola taman kanak-kanak dengan optimal, baik itu secara perkembangan psikologis, pertumbuhan biologis, kesehatan dan lain-lain. Apabila tumbuh kembang anak dapat difasilitasi secara optimal, maka negara akan memperoleh generasi yang berkualitas baik, yang akan mampu membangun bangsanya sendiri.

Karakteristik perkembangan motorik anak taman kanak-kanak berada pada tahapan pembentukkan gerak serta peningkatan berbagai variasi dari pola gerak yang dimilikinya. Tahapan-tahapan pembentukkan gerak pada anak taman kanak-kanak merupakan awal dari perkembangan motorik selanjutnya. Apabila perkembangan motorik anak di usia dini tidak berkembang baik, maka akan berdampak pada perkembangan motorik selanjutnya. Anak akan mengalami kesulitan dalam melakukan gerakan-gerakan yang kompleks seperti koordinasi, keseimbangan, kelincahan dan sebagainya.

Dunia anak taman kanak-kanak merupakan dunia aktif bergerak dan bermain sebagaimana Davis (2009, p.113) "these recommendations are grounded on notions that children are competent, active agents in their own lives". Ditambahkan lagi dari pendapat Tomoliyus (2012, p.4) "Dunia pendidikan taman kanak-kanak adalah sebuah dunia yang tidak terlepas dari aktivitas jasmani dengan bermain". Dari pendapat tersebut dapat disimpulkan bahwa belajar anak taman kanak-kanak adalah dengan bermain. Melalui bermain, anakanak akan memperoleh pengalaman gerak dan pengalaman informasi yang bermakna.

Taman kanak-kanak adalah pendidikan pra-sekolah yang mempersiapkan anak untuk menuju jenjang pendidikan selanjutnya. Anak diperkenalkan pengetahuan, sikap berperilaku yang baik, keterampilan, dan kemampuan bersosial sesama teman dan lingkunganya. Proses tersebut sebagai bekal untuk kegiatan belajar sesungguhnya di sekolah dasar (SD), oleh karenanya tidak berlebihan namun salah kaprah ketika anak taman kanak-kanak diajarkan membaca, menulis, dan berhitung secara langsung. Hal ini menyebabkan banyak lembaga taman kanak-kanak yang lebih mengedepankan atau mementingkan pengembangan kognitif dan afektif dan agak mengabaikan pengembangan kebugaran jasmani atau aktivitas motorik anak.

Dari hasil observasi yang dilakukan peneliti menunjukkan bahwa, di taman kanakkanak belajar mengenal huruf dan angka hanya dilakukan di dalam kelas dengan menulis hurufhuruf atau angka di buku/modul. Proses pembelajaran demikian menghasilkan perkembang- 
an motorik halus yang lebih dominan sedangkan perkembangan motorik kasar dan gerak manipulatif kurang berkembang secara optimal. Selain itu dari informasi beberapa guru taman kanak-kanak, menyatakan bahwa banyak anak selalu aktif bergerak, tetapi ada juga sebagian anak yang kurang aktif bergerak. Kondisi demikian kadang membuat guru bingung untuk memilih pendekatan pembelajaran yang tepat. Ditambahkan pula dari hasil penelitian yang dilakukan Rolina (2010, p.136) bahwa hampir $75 \%$ anak taman kanak-kanak merasa kurang termotivasi, enggan berangkat ke sekolah, dan anak kurang berminat dalam mengikuti pembelajaran, disebabkan karena anak-anak dicekoki hal-hal yang membosankan; anak harus belajar membaca, menulis, dan berhitung (calistung). Cara demikian dapat membuat anak kurang termotivasi untuk belajar karena pembelajaran tidak menggunakan belajar yang sesuai dengan karakteristik anak yakni senang bermain. Ada yang berpendapat bahwa anak taman kanak-kanak merupakan persiapan anak untuk pendidikan selanjutnya sehingga sudah harus diajarkan membaca, menulis, dan berhitung. Di lain pihak ada yang berpendapat anak taman kanak-kanak belum saatnya diajarkan membaca, menulis, dan berhitung, dikhawatirkan akan menjadi beban anak, sehingga timbul perasaan benci dengan kata "belajar", oleh karena itu, pembelajaran dengan menggunakan pendekatan permainan tematik integratif asumsinya akan lebih cocok bagi anak taman kanakkanak.

Berdasarkan hasil observasi dan informasi di atas, maka penelitian "Model permainan tematik integratif untuk meningkatkan kebugaran jasmani, mengenal huruf dan angka pada anak taman kanak-kanak", perlu dilakukan dengan harapan penelitian ini akan mampu: (1) Mengembangkan kegiatan aktivitas jasmani melalui permainan mengenal huruf dan angka untuk menyeimbangkan perkembangan motorik kasar dan motorik halus, (2) mengembangkan kegiatan aktivitas jasmani melalui permainan mengenal huruf dan angka di luar ruangan yang disusun secara sistematik yang berorientasi mendukung tumbuh kembang anak yang optimal dari aspek Fisik/motorik, kognitif, bahasa, sosial/emosional, nilai-nilai agama dan norma, (3) membantu guru taman kanak-kanak dengan mengajak anak yang aktif bergerak dan kurang aktif bergerak untuk belajar bersamasama, (4) mengajak anak bermain seraya belajar, dengan tanpa mengambil hak anak untuk bermain dan tanpa mengabaikan kewajiban anak untuk belajar (pembelajaran dengan pendekatan permainan), (5) memotivasi anak untuk belajar mengenal huruf dan angka, dan (6) mencoba berpartisipasi dalam mendukung program kurikulum 2013.

Permainan tematik integratif merupakan salah satu model pembelajaran yakni model pembelajaran dengan pendekatan bermain seraya belajar. Menurut Joyce \& Weil (2012, pp.56) dalam pengembangan model pembelajaran secara operasional memiliki lima aspek yang harus dikembangkan yakni: (1) syntax, (2) social system, (3) principles of reaction, (4) support system, (5)instructional and nurturant effects. Selain telah memperhatikan aspek-aspek pengembangan tersebut, ada beberapa prinsip yang perlu diperhatikan dalam pelaksanaan kegiatan/pembelajaran taman kanak-kanak antara lain: (1) berorienatasi pada perkembangan anak, (2) berorienatasi pada kebutuhan anak, (3) bermain seraya belajar, (4) stimulasi terpadu, (5) lingkungan kondusif, (6) menggunakan tematik, (7) Aktif, kreatif, inovatif, efektif, dan menyenangkan, (8) menggunakan berbagai media dan sumber belajar, (9) mengembangkan kecakapan hidup, (10) pemanfaatan teknologi informasi, dan (11) pembelajaran bersifat demokratisDalam proses pengembangan permainan tematik integratif telah mengacu pada aspek-aspek tersebut (Trianto, 2011, pp.73-76).

Menurut Paiman (2009, p.273) kebugaran jasmani ada tiga komponen yang dibagi tiga kelompok di antaranya adalah: (1) kebugaran jasmani yang berhubungan dengan kesehatan yang terdiri dari: daya tahan jantung paru, kekuatan otot, daya tahan otot, kelenturan, dan komposisi tubuh, (2) kebugaran jasmani berhubungan dengan keterampilan terdiri dari: keseimbangan (stability), daya ledak, kecepatan (speed), koordinasi, dan kecepatan reaksi, dan (3) kebugaran jasmani berhubungan dengan keadaan tidak menderita sakit (wellness). Kebugaran jasmani anak usia dini atau anak taman kanak-kanak termasuk ke kebugaran jasmani berdasarkan keadaan. Kebugaran jasmani berdasarkan keadaan diasumsikan kebugaran jasmani untuk menstimulus pertumbuhan anak melalui aktivitas bermain seraya belajar.

Pengenalan huruf dengan permainan mengenal huruf dapat dijadikan salah satu alternatif untuk menghindarkan dan meminimalisir anak mengalami disleksia. Anak disleksia merupakan salah satu jenis anak yang mengalami kesulitan belajar (learning disability). Kesulitan 
belajar yang dialami oleh anak disleksia adalah kesulitan belajar membaca (Praptiningrum, 2009, p.179). Jika anak sudah kesulitan dalam hal membaca maka anak juga akan mengalami kesulitan dalam belajar akademik. Disinilah peran guru dan orangtua untuk membantu dan membimbing anak agar anak mempunyai ketertarikan untuk belajar, anak setingkat taman kanak-kanak cukup belajar dengan mengenal huruf-huruf. Menurut Ehri \& McCormik, Seefeldt (2008, p.330) belajar abjad adalah komponen hakiki dari perkembangan baca tulis. Ketika anak-anak mulai memperhatikan huruf cetak pada sebuah halaman buku, anak juga tertarik pada huruf-huruf yang membentuk kata dan menimbulkan rasa ingin tahu anak, dengan demikian peran orangtua dan guru sangatlah diperlukan sebagaimana menurut Rusijono (2007, p.134) "kalau anak sudah siap belajar membaca tetapi tidak mendapat respons atau diberikan kegiatan sesuai dengan perkembangannya maka minat anak untuk belajar membaca akan hilang". Dapat disimpulkan bahwa jika melihat dari perkembangan anak, maka pendekatan yang paling efektif adalah melalui bermain sesuai dengan karakteristik anak yang suka bermain.

Permainan tematik integratif sebagai solusi dan menekan beberapa faktor yang dapat meningkatkan risiko kesulitan anak belajar matematika, "factors elevate a child's risk of mathematics difficulties (MD)" (Morgan, 2009, p.306). Kesulitan belajar matematika (mathematics difficulties) tesebut dapat diterapkan dalam Pendidikan Matematika Realistik (PMR). Menurut Athar (2011, p.44) Pendidikan Matematika Realistik (PMR) adalah suatu pendekatan pembelajaran yang menggunakan masalahmasalah kontekstual (contextual problems) sebagai langkah awal dalam proses pembelajaran. Selain Pendidikan Matematika Realistik (PMR) ada juga alternatif yang lain untuk meningkatkan kemampuan belajar Matematika yakni dengan teori belajar sosiokultural, yakni teori belajar yang menekankan pada latar belakang sosial dan budaya seseorang (Condro, 2009, pp.167-168).

Berhitung dalam penelitian ini merupakan penerapan dari Pendidikan Matematika Realistik (PMR) dan teori belajar sosiokultural yakni dengan berlandaskan anak taman kanakkanak belum bisa berpikir abstrak dan mengingat latar belakang anak taman kanak-kanak merupakan masa-masa bermain atau belajarnya anak taman kanak-kanak melalui bermain, sehingga harapannya dengan permainan tematik integratif sebagai awal untuk menumbuhkan dan meningkatkan minat anak-anak terhadap pembelajaran berhitung seperti pelajaran matematika, fisika, kimia dan lain-lain.

Anak taman kanak-kanak merupakan bagian dari anak usia dini, secara kasat mata dapat didiskripsikan bahwa anak taman kanakkanak merupakan anak yang mungil, aktif, menggemaskan, lucu, dan penuh rasa ingin tahu (selalu ingin bertanya). Karakteristik anak pada umumnya sama, namun yang dapat membedakan adalah pengalaman yang didapatkan oleh anak. Anak yang mendapat kesempatan belajar di taman kanak-kanak memperoleh pengalaman yang maksimal, baik itu pengalaman gerak maupun pengalaman informasi (pengetahuan) sehingga pertumbuhan dan perkembangan terstimulus secara optimal, sedangkan anak yang tidak mendapat kesempatan belajar di taman kanak-kanak diasumsikan secara pertumbuhan dan perkembangan belum tercapai secara optimal. Menurut Trianto (2011, p.32) Pendidikan anak usia dini (early chilhood education) merupakan suatu disiplin ilmu pendidikan yang khusus memperhatikan, menelaah, dan mengembangkan berbagai interaksi edukatif antara anak usia dini dan pendidik untuk mencapai tumbuh kembang potensi anak secara optimal.

\section{Metode Penelitian}

Metode dalam penelitian permainan tematik integratif termasuk ke dalam penelitian dan pengembangan atau Research and Development (R/D). Menurut Bold \& Gall (2007, p.589) "research and development ( $R$ and $D)$ is an insdustry-based development model in which the findings of research are used to design new products and prosedures, which then are systematically field-tested, evaluate, and refined until they meet specified criteria of effectivness, quality, or similar standards". Maksudnya adalah Penelitian dan pengembangan adalah model pembangunan berbasis insdustri di mana temuan penelitian yang digunakan untuk merancang produk baru dan berprosedur, yang kemudian secara sistematis teruji di lapangan, mengevaluasi, dan disempurnakan sampai model pengembangan memenuhi kriteria yang ditentukan oleh efektivitas, kualitas atau berstandar.

Menurut Sugiyono (2010, p.407) "penelitian dan pengembangan adalah metode penelitian yang digunakan untuk menghasilkan produk tertentu, dan menguji keefektifan 
produk tersebut". Secara sederhana research and development dapat didefinisikan sebagai metode penelitian yang secara sengaja, sistematis, bertujuan untuk mencari, menemukan, merumuskan, memperbaiki, mengembangkan, menghasilkan, menguji keefektifan produk, dengan prosedur tertentu yang lebih unggul, efektif, efisien, produktif dan bermakna (Putra, 2012, p.67). Berdasarkan pengertian di atas, maka model permainan tematik integratif untuk meningkatkan kebugaran jasmani, mengenal huruf dan angka pada anak taman kanak-kanak merupakan penelitian untuk menemukan dan mencari solusi dari permasalahan yang ada di pembelajaran taman kanak-kanak melalui aktivitas jasmani

Rancangan penelitian permainan tematik integratif merupakan penelitian dan pengembangan (Research and Development) dengan langkah-langkah sebagai berikut: (1) potensi dan masalah, (2) pengumpulan data, (3) desain produk, (4) validasi desain, (5) revisi desain, (6) uji coba produk, (7) revisi produk, (8) uji coba produk, (9) revisi produk, dan (10) produksi masal (Sugiyono, 2010, pp.409-426)

Berikut ini adalah langkah-langkah penelitian dan pengembangan serta penjelasannya:

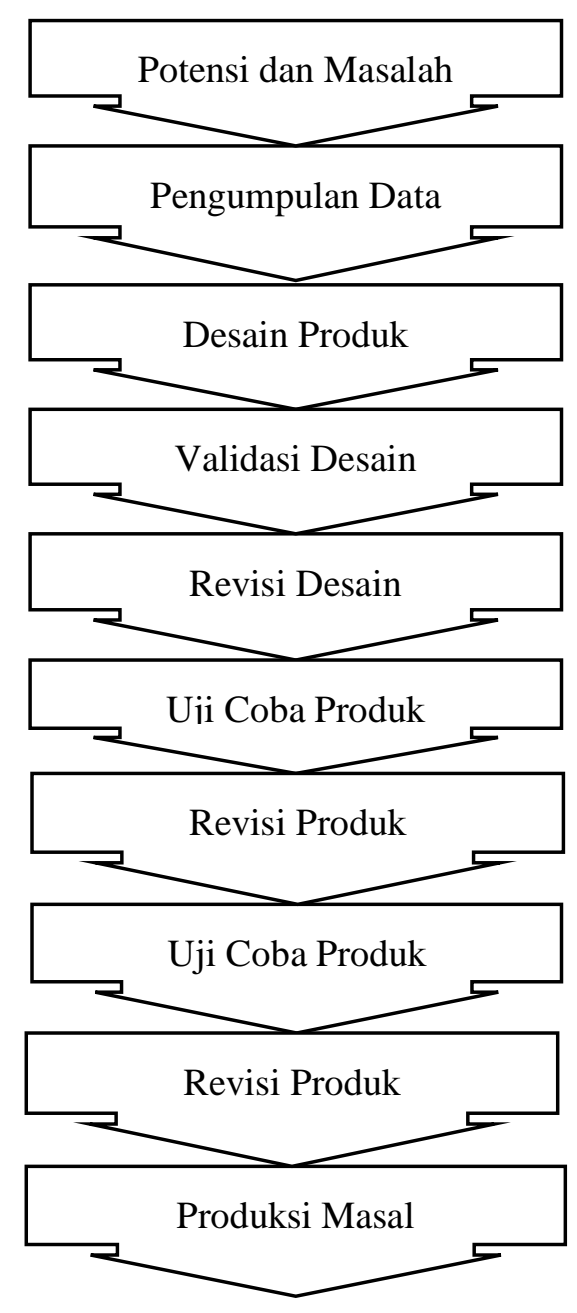

Gambar 1. Desain Prosedur Pengembangan

Potensi dan Masalah

Penelitian dapat berasal dari adanya potensi-potensi suatu masalah yang ditemukan. Potensi adalah segala sesuatu yang bila didayagunakan akan memiliki nilai tambah, sedangkan masalah adalah penyimpangan yang diharapkan dengan yang terjadi. Dalam penelitian yang akan diteliti potensi dan masalahnya adalah (1) metode pembelajaran mengenal huruf dan angka di taman Kanak-kanak hanya dilakukan di dalam kelas dengan menulis huruf-huruf dan angka di buku/modul, dilihat dari aspek perkembangan anak maka perkembangan motorik halus yang lebih dominan berkembang sehingga perkembangan motorik kasar dan gerak manipulatif tidak berkembang optimal, (2) karakteristik anak yang aktif bergerak dan ada juga anak yang pasif bergerak, dengan demikian kadang-kadang guru bingung untuk mencari solusi permalasahan seperti ini, (3) dari hasil penelitian survey Rolina (2010, p.136) pada kenyataanya hampir $75 \%$ anak taman kanak-kanak merasa bosan dan enggan 
berangkat ke sekolah, serta kurang berminat anak dalam mengikuti pembelajaran karena dalam proses belajar kurang menarik dan menyenangkan, dan (4) ada pandangan bahwa dengan mengajarkan anak membaca, menulis, dan berhitung pada usia dini dikhawatirkan akan menjadi beban anak, sehingga timbul perasaan benci dengan kata "belajar', dilain pihak ada yang berpandangan bahwa anak-anak belum boleh diberikan pelajaran-pelajaran seperti menulis, membaca, berhitung dan membiarkan anak hanya bermain semata. Dengan demikian perlu diteliti dan dikembangkan suatu metode pembelajaran yang menarik, menyenangkan dan bermakna yakni melalui permainan tematik integratif untuk meningkatkan kebugaran jasmani anak, mengenal huruf dan angka pada anak taman kanak-kanak. Kebermaknaan dalam permainan ini adalah dapat mendukung pertumbuhan dan perkembangan anak yang optimal serta menciptakan anak yang cerdas, kuat, dan tangguh.

\section{Megumpulkan Informasi}

Setelah potensi dan masalah dapat ditunjukkan secara faktual dan terbaru (up todate), langkah berikut adalah mengumpulkan berbagai informasi yang benar digunakan sebagai bahan untuk perencanaan pembuatan produk yang diharapkan dapat mengatasi potensipotensi masalah yang ada. Informasi-informasi didapatkan dari masalah penelitian adalah hasil informasi yang diperoleh dari perkembangan pendidikan taman kanak-kanak baik itu media cetak maupun media elektronik serta survei beberapa guru taman kanak-kanak.

Desain Produk

Produk yang dihasilkan dalam penelitian dan pengembangan (research and development) bermacam-macam (Sugiyono, 2010, p.412). Produk-produk yang dihasilkan melalui penelitian dan pengembangan diharapkan dapat meningkatkan produktivitas pendidikan, sebagai contoh yakni kurikulum yang spesifik untuk keperluan pendidikan tertentu, metode mengajar, media pendidikan, buku ajar, modul, kompetensi tenaga kependidikan, sistem evaluasi dan lain-lain.

Desain produk permainan tematik integratif dapat didikripsikan sebagai berikut, setiap anak akan menjalani rangkaian-rangkaian aktivitas jasmani, mengenal huruf (huruf kecil), dan angka. Setiap permainan mengenal huruf dan angka berdasarkan tema yang ada di kuri- kulum Taman Kanak-kanak dan tingkat pencapaian perkembangan anak. Tema-tema yang ada di kurikulum pendidikan taman kanak-kanak diantaranya; diri sendiri, lingkunganku, kebutuhanku, binatang, dam tanaman. Sedangkan tingkat pencapaian perkembangan meliputi fisik/motorik, kognitif, bahasa, sosial/emosional, nilai-nilai norma dan agama. Kata-kata yang akan dipilih yakni berjumlah antara 4 sampai 5 huruf, kriteria dari kata-kata yang diberikan kepada anak-anak adalah suku kata yang sering didengar dan sesuatu benda yang sering dijumpai dalam kehidupan sehari-hari serta kata-kata yang paling sederhana, sedangkan untuk mengenal angka yakni angka 1-10 $(1 / 2 / 3 / 4 / 5 / 6 / 7 / 8 / 9 / 10)$. Permainan tematik integratif merupakan permainan edukatif yang mengajak anak bermain seraya belajar secara bersama-sama.

Model permainan tematik integratif yang akan dikembangkan terdapat 6 macam permainan, yakni; (1) permainan Kupu-kupu Terbang, (2) permainan lompat Kelinci, (3) permainan Terbang Pesawat, (4) Lompat Balok, (5) permainan Ular dan Katak, dan (6) permainan Jalan Kepiting. Dari keenam desain permainan tematik integratif tersebut, permainan tematik integratif banyak mengajarkan anak-anak yang berkaitan dengan: (1) meningkatkan kebugaran jasmani (menstimulus pertumbuhan dan perkembangan). Kebugaran jasmani pada permainan tematik integratif merupakan kebugaran untuk mensitmulus perkembangan dan pertumbuhan anak yakni melalui aktivitas jasmani. Permainan yang dikembangkan ini mengajarkan anak untuk beraktivitas jasmani melalui aktivitas memperagakan gerakan-gerakan binatang atau benda. Sedangkan untuk perkembangan anak distimulus untuk menumbuhkan minat belajar (kognitif), memupuk anak berjiwa sosial/emosional, dan menerapkan norma-norma sosial dan agama, (2) mengajak anak belajar mengenal huruf atau angka. Permainan tematik integratif mengembangkan metode bermain sambil belajar, belajar pada permainan tematik integratif adalah mengenal huruf atau angka. Dalam permainan huruf dan angka, anak tidak saja dikenalkan dengan bentuk huruf atau angka saja, namun lebih kompleks, anak juga dilatih untuk teliti dan belajar konsenterasi dalam membedakan bentuk huruf/angka, warna dan gambar, (3) enstimulus dan melatih perkembangan motorik. Permainan tematik integratif mengajarkan anak untuk memperagakan gerakan-gerakan binatang atau benda, dari gerakan 
binatang atau benda anak mendapatkan pengalaman gerak yakni untuk melatih perkembangan motorik kasar, dan motorik halus. Dengan demikian potensi-potensi yang dimiliki anak dapat dikembangkan melalui permainan ini. Pengalaman yang dialami oleh anak akan berpengaruh kuat terhadap kehidupan selanjutnya, ketika anak beraktivitas gerak penyesuaian terhadap gerakan yang dipelajari akan lebih mudah, selain itu ketika anak menghadapi keadaan dan kondisi yang mengancam dirinya anak dapat meminimalisir terjadinya cidera sebagai contoh ketika anak bersepeda kemudian terjatuh, maka anak akan melompat secepat mungkin, ini dikarenakan anak sudah mempunyai pengalaman gerak dimemori otaknya, (4) melatih kesadaran gerak (movement awareness). Permainan tematik integratif merupakan permainan yang kompleks dalam hal aktivitas jasmani dan gerak. Dari keenam bentuk permainan tematik integratif dapat melatih kesadaran gerak anak seperti: Body awareness (mengetahui dan memahami nama dan fungsi macam-macam bagian tubuh). Directional awareness (kesadaran akan arah), Vestibular awareness (keseimbangan), tactile awareness (kesadaran perabaan), dan kesadaran koordinasi mata-tangan-kaki (eye-hand-eye-foot), melatih kebugaran motorik. Menurut Suharjana (2013, p.40) kebugaran jasmani yang terkait dengan keterampilan (kebugaran motorik) mencakup beberapa komponen yakni kecepatan, daya ledak, koordinasi, kelincahan, dan keseimbangan. Dari beberapa komponen kebugaran motorik tersebut diajarkan atau dilatih dalam permainan tematik integratif.

\section{Validasi Desain}

Validasi produk dapat dilakukan dengan cara menghadirkan pakar atau tenaga pakar yang sudah berpengalaman di bidang masing-masing yang berkaitan dengan variabelvariabel yang ada untuk menilai produk yang akan dikembangkan. Pakar diminta untuk menilai kesesuaian antara permainan yang dikembangkan dengan karakteristik pertumbuhan dan perkembangan anak. Dari hasil validasi desain para pakar dapat diketahui kelemahan dan kekurangan permainan. Penelitian model permainan tematik integratif yang dikembangkan akan diujikan kepada pakar (Expert Judgement) dibeberapa bidang, pakar-pakar tersebut antara lain: (1) pakar di bidang pendidikan anak usia dini (PAUD) dimohonkan kepada yang terhormat Prof. Dr. Sukadiyanto, M.Pd, (2) pakar di bidang pendidikan jasmani dan permainan dimohonkan kepada yang terhormat Dr. Pamuji Sukoco, M.Pd, (3) praktisi dimohonkan kepada guru Taman Kanak-kanak Bustanul Athfal Karangmalang yang terhormat, Roni Ismiyatun, S.Pd.I. Guru Taman Kanak-kanak Nasional Samirono, Sri Aminah. Guru Taman Kanakkanak Kartini Karanggayam, Ika Sugiyarti, (4) pakar media dimohonkan kepada yang terhormat, Hery Nurmawan, S.Kom.

\section{Perbaikkan Desain}

Perbaikan desain dalam penelitian yang akan dikembangkan yakni dengan cara memvalidasi produk melalui diskusi dengan para pakar di bidang masing-masing, sehingga hasil desain produk dapat diketahui kelemahan dan kekurangan yang ada.

\section{Uji Coba Produk}

Setelah divalidasi dan perbaikan desain, kemudian produk dapat diujicobakan. Penelitian model permainan tematik integratif diuji cobakan skala kecil yakni Taman KanakKanak Bustanul Athfal Karangmalang yang berjumlah 26 anak di kelompok (B2).

\section{Revisi Produk}

Setelah diujicobakan dalam skala kecil yakni berjumlah 26 anak, maka dari hasil penelitian tersebut dikonsultasikan lagi kepada pakar di bidang masing-masing kemudian direvisi kembali.

\section{Uji coba Pemakaian}

Setelah direvisi kemudian diujicobakan kembali dalam skala besar yakni Taman Kanakkanak Nasional Samirono berjumlah 18 anak, dan Taman Kanak-Kanak Kartni Karanggayam 18 anak.

Revisi Produk

Setelah diujicobakan kemudian dikonsultasikan kembali kepada pakar di bidang masing-masing kemudian direvisi kembali.

\section{Pembuatan Produk Masal}

Setelah melewati beberapa proses tersebut maka produk model permainan tematik integratif untuk meningkatkan kebugaran jasmani, mengenal huruf dan angka anak taman kanak-kanak dapat diaplikasikan di pembelajaran taman kanak-kanak dan dipasarkan. 
Tempat dan Waktu Pengembangan

Penelitian model permainan tematik integratif akan dilaksanakan dibeberapa Taman Kanak-kanak di kabupaten Sleman. Penelitian uji coba skala kecil dilaksanakan di Taman Kanak-kanak Aisyiyah Bustanul Athfal Karangmalang. Penelitian uji coba skala besar dilaksanakan di dua sekolah yakni Taman Kanak-kanak Nasional Samirono, dan Taman Kanak-Kanak Kartini Karanggayam. Waktu penelitian mulai dari bulan November 2013 sampai dengan bulan Desember 2013.

Teknik Analisis Data

Teknik analisis data yang diperoleh melalui kegiatan uji coba produk yang akan di analisis dan diklasifikasikan menjadi dua data yaitu data kualitatif dan kuantitatif. Data kualitatif berupa penilaian, kritik, serta saran yang dikemukakan oleh pakar, dari beberapa saran yang diperoleh kemudian akan digunakan untuk keperluan perbaikan dan penyempurnaan model permainan yang akan dikembangkan dan dihasilkan.

Teknik analisis kuantitatif dalam penelitian ini menggunakan analisis statistik deskriptif, yang berupa pertanyaan. Jawaban setiap butir instrumen menggunakan skara Likert yang bergradasi sangat baik sampai dengan sangat kurang dengan model 5 pilihan (skala lima). Pemberian nilai dari pertanyaan tersebut yakni pernyataan sangat kurang, kurang, cukup, baik dan sangat baik yang diubah menjadi data kuantitatif dengan skala 5 yaitu dengan penskoran dari angka 1 s/d 5. Kemudian dikonversikan menjadi data kualitatif yakni mengetahui nilai maksimal (ideal) $=$ (skor butir maksimal) x (butir pertanyaan) x (jumlah pakar dan praktisi). Nilai minimal $=$ (skor butir minimal) $\mathrm{x}$ (butir pertanyaan) x (jumlah pakar dan praktisi). Kelas interval $=5$. Jarak kelas interval $=$ nilai maksimal dikurangi nilai minimal dibagi jumlah kelas interval. Berikut ini adalah tabel konversi data kuantatif ke data kualitatif dengan skala 5. Perhitungan di atas diadaptasi menurut (Widoyoko, 2012, pp.114115).
Tabel 1.Konversi Data Kuantitif ke Data Kualitatif dengan Skala 5.

\begin{tabular}{ccc}
\hline $\begin{array}{c}\text { Klasifikasi } \\
\text { Data } \\
\text { Kuantitatif }\end{array}$ & $\begin{array}{c}\text { Jumlah Skor } \\
\text { Jawaban }\end{array}$ & $\begin{array}{c}\text { Klasifikasi Data } \\
\text { Kualitatif }\end{array}$ \\
\hline 5 & $182-216$ & Sangat Baik \\
4 & $147-181$ & Baik \\
3 & $112-146$ & Cukup \\
2 & $77-111$ & Kurang \\
1 & $42-76$ & Sangat Kurang \\
\hline
\end{tabular}

\section{Hasil Penelitian dan Pembahasan}

Deskripsi Desain Produk Awal

Setelah menentukan produk yang akan dikembangkan berupa materi permainan tematik integratif yang sesuai dengan kebutuhan anak taman kanak-kanak yakni bermain sambil belajar. Selanjutnya tahapan yang dilakukan adalah menyusun produk dengan menggunakan langkah-langkah yakni: (1) analisis tujuan dan karakteristik permainan tematik integratif, dalam hal ini permainan aktivitas jasmani, mengenal huruf dan angka pada anak taman kanakkanak, (2) analisis karakteristik anak taman kanak-kanak, (3) mengkaji literatur tentang prinsip-prinsip atau cara pengembangan permainan, (4) menetapkan tujuan, isi, dan strategi kegiatan permainan, (5) menentukan tingkat pencapaian perkembangan dan tujuan bermain sambil belajar, dan (6) menyusun desain modelmodel permainan tematik integratif. Setelah melalui langkah-langkah tersebut maka dihasilkan desain awal dari materi permainanpermainan tematik integratif untuk meningkat kebugaran jasmani, mengenal huruf, dan angka pada anak taman kanak-kanak dengan menghasilkan enam macam permainan yakni: (1) permainan Kupu-kupu Terbang (mengenal huruf), (2) permainan Lompat Kelinci (mengenal angka), (3) permainan Pesawat Terbang (mengenal huruf), (4) permainan Lompat Balok (mengenal angka), (5) permainan Ular dan Katak (mengenal huruf), dan (6) permainan Jalan Kepiting (mengenal angka).

Hasil Uji Coba Produk

\section{Validasi Desain Permainan}

Sebelum dilakukannya penelitian uji coba skala kecil dan uji coba skala besar, desain model permainan tematik integratif ini divalidasi terlebih dahulu oleh para pakar dan praktisi. Berikut adalah hasil validasi yang diperoleh dari para pakar dan praktisi. 
Dari data penilaian hasil validasi para pakar dan praktisi, selanjutnya akan diubah menjadi data kuantitatif yang akan dikonversikan dari data kuantatif ke data kualitatif dengan skala lima yang diadopsi dari Widoyoko (2012, pp.114-115) nilai maksimal (ideal) $=5$ (skor butir maksimal) x 16 (butir pertanyaan) x 3 (jumlah pakar dan praktisi $)=240$. Nilai minimal 1 (skor butir maksimal) x 14 (butir pertanyaan) x 3 (jumlah pakar dan praktisi) $=38$. Kelas interval $=5$. Jarak kelas interval $=$ nilai maksimal dikurangi nilai minimal dibagi jumlah kelas interval $=(240-38) / 5=38$. Berdasarkan hasil tersebut maka dapat disusun klasifikasi yang akan digunakan sebagai pedoman dalam konversi skor pada semua aspek ke dalam kriteria penilaian permainan tematik integratif, untuk lebih jelas berikut akan disajikan klasifikasi penilaian dalam bentuk tabel:

Tabel 2. Konversi Data Kuantitif ke Data Kualitatif dengan Skala 5.

\begin{tabular}{ccc}
\hline $\begin{array}{c}\text { Klasifikasi } \\
\text { Data } \\
\text { Kuantitatif }\end{array}$ & $\begin{array}{c}\text { Jumlah Skor } \\
\text { Penilaian }\end{array}$ & $\begin{array}{c}\text { Klasifikasi Data } \\
\text { Kualitatif }\end{array}$ \\
\hline 5 & $204-242$ & Sangat baik \\
4 & $165-203$ & Baik \\
3 & $126-164$ & Cukup \\
2 & $87-125$ & Kurang \\
1 & $48-86$ & Sangat Kurang \\
\hline
\end{tabular}

Berdasarkan tabel hasil skala penilaian dari pakar pendidikan olahraga usia dini, pakar permainan, dan praktisi tersebut, maka dapat disimpulkan: (1) permainan Kupu-kupu Terbang memiliki nilai 173 (165-203) berkategori "baik", (2) permainan Lompat Kelinci memiliki nilai 168 (165-203) berkategori "baik, (3) permainan Pesawat Terbang memiliki nilai 166 (165-203) berkategori "baik".

Penilaian yang diperoleh dari pakar dan praktisi terhadap permainan Lompat Balok, permainan Ular dan Katak, serta permainan Jalan Kepiting, maka dapat disusun klasifikasi nilai yang digunakan sebagai pedoman dalam konversi skor pada semua aspek permainan ke dalam kriteria penilaian sebagai berikut:
Tabel 3. Konversi Data Kuantitif ke Data Kualitatif dengan Skala 5

\begin{tabular}{ccc}
\hline $\begin{array}{c}\text { Klasifikasi } \\
\text { Data } \\
\text { Kuantitatif }\end{array}$ & $\begin{array}{c}\text { Jumlah Skor } \\
\text { Penilaian }\end{array}$ & $\begin{array}{c}\text { Klasifikasi Data } \\
\text { Kualitatif }\end{array}$ \\
\hline 5 & $182-216$ & Sangat Baik \\
4 & $147-181$ & Baik \\
3 & $112-146$ & Cukup \\
2 & $77-111$ & Kurang \\
1 & $42-76$ & Sangat Kurang \\
\hline
\end{tabular}

Berdasarkan tabel hasil penilaian dari pakar pendidikan olahraga usia dini, pakar permainan, dan praktisi di atas, menunjukkan bahwa: (1) permainan Lompat Balok memiliki nilai 160 (147-181) berkategori "Baik", (2) permainan Ular dan Katak memiliki nilai 165 (147-181) berkategori "Baik, (3) permainan Jalan Kepiting memiliki nilai 166 (147-181) berkategori "Baik".

\section{Uji Coba Skala Kecil}

Uji coba skala kecil dilaksanakan di Taman Kanak-kanak Aisyiyah Karangmalang, subyek uji coba skala kecil yakni Taman Kanak-kanak Aisyiyah Karangmalang kelompok $\mathrm{B}$, dengan jumlah 25 anak.

Dari hasil penilaian uji coba skala kecil yang diperoleh melalui pakar pendidikan olahraga usia dini, pakar permainan, dan praktisi terhadap permainan Lompat Kupu-kupu Terbang, permainan Lompat Kelinci, dan permainan Pesawat Terbang, maka dapat disusun klasifikasi penilaian yang digunakan sebagai pedoman dalam memberikan kriteria penilaian permainan yakni:

Tabel 4. Konversi Data Kuantitif ke Data Kualitatif dengan Skala 5

\begin{tabular}{ccc}
\hline $\begin{array}{c}\text { Klasifikasi } \\
\text { Data } \\
\text { Kuantitatif }\end{array}$ & $\begin{array}{c}\text { Jumlah Skor } \\
\text { Penilaian }\end{array}$ & $\begin{array}{c}\text { Klasifikasi Data } \\
\text { Kualitatif }\end{array}$ \\
\hline 5 & $204-242$ & Sangat Baik \\
4 & $165-203$ & Baik \\
3 & $126-164$ & Cukup \\
2 & $87-125$ & Kurang \\
1 & $48-86$ & Sangat Kurang \\
\hline
\end{tabular}

Berdasarkan tabel hasil skala penilaian dari para pakar dan praktisi di atas, maka dapat disimpulkan: (1) permainan Kupu-kupu Terbang memiliki nilai 205 (204-242) berkategori "Sangat Baik", (2) permainan Lompat Kelinci memiliki nilai 206 (204-242) berkategori "Sangat Baik, (3) permainan Pesawat Terbang 
memiliki nilai 205 (204-242) berkategori "Sangat Baik".

Berdasarkan hasil penilaian yang diperoleh dari pakar pendidikan olahraga usia dini, pakar permainan, dan praktisi terhadap permainan Lompat Balok, permainan Ular dan Katak, serta permainan Jalan Kepiting, maka dapat disusun klasifikasi nilai yang digunakan sebagai pedoman dalam konversi skor pada semua aspek permainan ke dalam kriteria penilaian sebagai berikut:

Tabel 5. Konversi Data Kuantitif ke Data Kualitatif dengan Skala 5

\begin{tabular}{ccc}
\hline $\begin{array}{c}\text { Klasifikasi } \\
\text { Data } \\
\text { Kuantitatif }\end{array}$ & $\begin{array}{c}\text { Jumlah Skor } \\
\text { Penilaian }\end{array}$ & $\begin{array}{c}\text { Klasifikasi Data } \\
\text { Kualitatif }\end{array}$ \\
\hline 5 & $182-216$ & Sangat Baik \\
4 & $147-181$ & Baik \\
3 & $112-146$ & Cukup \\
2 & $77-111$ & Kurang \\
1 & $42-76$ & Sangat Kurang \\
\hline
\end{tabular}

Tabel di atas merupakan hasil penilaian dari pakar pendidikan olahraga usia dini, pakar permainan, dan praktisi, dengan demikian dapat disimpulkan bahwa: (1) permainan Lompat Balok memiliki nilai 182 (182-216) berkategori "Sangat Baik", (2) permainan Ular dan Katak memiliki nilai 183 (182-216) berkategori "Sangat Baik, (3) permainan Jalan Kepiting memiliki nilai 186 (182-216) berkategori "Sangat Baik".

Uji Keefektifan Permainan Tematik di Uji Coba Skala Kecil

Uji keefektifan permainan tematik integratif dapat diketahui dari hasil unjuk kerja anak dalam melakukan permainan yang dinilai oleh para praktisi. Uji keefektifan dapat diketahui juga dari hasil dilapangan, yakni ekspresi spontan dari tingkah laku anak seperti anak terlihat gembira, senang, bersorak-sorai, pantang menyerah, ketika berhasil melakukan seperti memadupandakan huruf atau angka, anak-anak berteriak "horee", "yess" (yaaaa), dan bahkan ada beberapa anak bertanya "kapankapan main lagi ya kak?!". Selain itu, uji keefektifan dapat diketahui melalui hasil observasi yang dinilai oleh pakar pendidikan olahraga usia dini, pakar permainan, dan praktisi, maka dapat disusun klasifikasi nilai yang digunakan sebagai pedoman dalam konversi skor pada semua aspek permainan ke dalam kriteria penilaian sebagai berikut:
Tabel 6. Konversi Data Kuantitif Ke Data kualitatif dengan Skala 5.

\begin{tabular}{ccc}
\hline $\begin{array}{c}\text { Klasifikasi } \\
\text { Data } \\
\text { Kuantitatif }\end{array}$ & $\begin{array}{c}\text { Jumlah Skor } \\
\text { Penilaian }\end{array}$ & $\begin{array}{c}\text { Klasifikasi Data } \\
\text { Kualitatif }\end{array}$ \\
\hline 5 & $130-152$ & Sangat baik \\
4 & $105-129$ & Baik \\
3 & $80-104$ & Cukup \\
2 & $55-79$ & Kurang \\
1 & $30-54$ & Sangat Kurang \\
\hline
\end{tabular}

Tabel uji keefektifan tersebut menyimpulkan bahwa: (1) permainan Kupu-kupu Terbang mempunyai jumlah nilai 130 , berkategori "sangat baik" (130-152), (2) permainan Lompat Kelinci mempunyai jumlah nilai 133 , berkategori "sangat baik" (130-152), dan (3) permainan Pesawat Terbang mempunyai jumlah nilai 134, berkategori "sangat baik" (130-152).

Berdasarkan penilaian hasil observasi yang diperoleh dari pakar pendidikan olahraga usia dini, pakar permainan, dan praktisi, maka dapat disusun klasifikasi kriteria penilaian sebagai berikut:

Tabel 7. Konversi Data Kuantitif ke Data Kualitatif dengan Skala 5.

\begin{tabular}{ccc}
\hline $\begin{array}{c}\text { Klasifikasi } \\
\text { Data } \\
\text { Kuantitatif }\end{array}$ & $\begin{array}{c}\text { Jumlah Skor } \\
\text { Penilaian }\end{array}$ & $\begin{array}{c}\text { Klasifikasi Data } \\
\text { Kualitatif }\end{array}$ \\
\hline 5 & $104-152$ & Sangat Baik \\
4 & $84-103$ & Baik \\
3 & $64-83$ & Cukup \\
2 & $44-63$ & Kurang \\
1 & $24-43$ & Sangat Kurang \\
\hline
\end{tabular}

Tabel uji keefektifan pada uji coba skala kecil di atas, menyimpulkan bahwa: (1) permainan Lompat Balok mempunyai jumlah nilai 116, berkategori "Sangat Baik" (104-152), (2) permainan Ular dan Katak mempunyai jumlah nilai 133, berkategori "Sangat Baik" (104-152), dan (3) permainan Jalan Kepiting mempunyai jumlah nilai 106, berkategori "Sangat Baik" (104-152), dengan demikian secara keseluruhan dapat disimpulkan bahwa permainan tematik integratif sudah dalam kategori efektif sehingga sudah dapat diajarkan dan diterapkan di pembelajaran mengenal huruf dan angka di taman kanak-kanak. 
Hasil Penilaian Pakar Media terhadap Video dan Buku Panduan Permainan Tematik Integratif pada Uji Coba Skala Kecil.

Berdasarkan hasil penilaian pakar media terhadap video dan buku panduan pada uji coba skala kecil, maka dapat disusun klasifikasi yang akan digunakan sebagai pedoman dalam konversi skor pada semua aspek ke dalam kriteria penilaian permainan tematik integratif, untuk lebih jelas berikut akan disajikan klasifikasi penilaian dalam bentuk tabel:

Tabel 8. Konversi Data Kuantitif ke Data Kualitatif dengan Skala 5

\begin{tabular}{ccc}
\hline $\begin{array}{c}\text { Klasifikasi } \\
\text { Data } \\
\text { Kuantitatif }\end{array}$ & $\begin{array}{c}\text { Jumlah Skor } \\
\text { Penilaian }\end{array}$ & $\begin{array}{c}\text { Klasifikasi Data } \\
\text { Kualitatif }\end{array}$ \\
\hline 5 & $47-55$ & Sangat Baik \\
4 & $38-46$ & Baik \\
3 & $29-37$ & Cukup \\
2 & $19-28$ & Kurang \\
1 & $10-18$ & Sangat Kurang \\
\hline
\end{tabular}

Hasil penilaian pakar media: (1) penilaian terhadap video permainan tematik integratif mempunyai jumlah nilai 44 , berkategori "Baik" (47-55), dan (2) penilaian buku permainan tematik integratif mempunyai jumlah nilai 43, berkategori "Baik" (47-55).

\section{Uji Coba Skala Besar}

Uji coba skala besar dilaksanakan di dua sekolah yakni; (1) penelitian di Taman Kanak-kanak Nasional Samirono, subjek uji coba pada kelompok B, jumlah 18 anak. Penelitian dilaksanakan dua kali pertemuan yakni hari Sabtu 14 Desember 2013 dan hari senin 16 Desember 2013, dan (2) penelitian di Taman Kanak-kanak Kartini Karanggayam, subjek uji coba pada kelompok B, jumlah 18 anak. Penelitian dilaksanakan dua kali pertemuan yakni hari Rabu 18 Desember 2013 dan Jumat 20 Desember 2013.

Dari data hasil penilaian para pakar dan praktisi, selanjutnya akan diubah menjadi data kuantitatif yang akan dikonversikan dari data kuantatif ke data kualitatif dengan skala lima. Berdasarkan hasil penilaian yang diperoleh, maka dapat disusun klasifikasi yang akan digunakan sebagai pedoman dalam konversi skor pada semua aspek ke dalam kriteria penilaian permainan tematik integratif:
Tabel 9.Konversi Data Kuantitif ke Data Kualitatif dengan Skala 5

\begin{tabular}{ccc}
\hline $\begin{array}{c}\text { Klasifikasi } \\
\text { Data } \\
\text { Kuantitatif }\end{array}$ & $\begin{array}{c}\text { Jumlah Skor } \\
\text { Penilaian }\end{array}$ & $\begin{array}{c}\text { Klasifikasi Data } \\
\text { Kualitatif }\end{array}$ \\
\hline 5 & $272-323$ & Sangat Baik \\
4 & $220-271$ & Baik \\
3 & $168-219$ & Cukup \\
2 & $116-167$ & Kurang \\
1 & $64-115$ & Sangat Kurang \\
\hline
\end{tabular}

Berdasarkan tabel hasil skala penilaian dari para pakar dan praktisi di atas, maka dapat disimpulkan: (1) permainan Kupu-kupu Terbang memiliki nilai 302 (272-323) berkategori "Sangat Baik", (2) permainan Lompat Kelinci memiliki nilai 309 (272-323) berkategori "Sangat Baik" (3) permainan Pesawat Terbang memiliki nilai 312 (272-323) berkategori "Sangat Baik".

Berdasarkan hasil penilaian yang diperoleh dari pakar dan praktisi terhadap permainan Lompat Balok, permainan Ular dan Katak, serta permainan Jalan Kepiting, maka dapat disusun klasifikasi nilai yang digunakan sebagai pedoman dalam konversi skor pada semua aspek permainan ke dalam kriteria penilaian sebagai berikut:

Tabel 10. Konversi Data Kuantitif ke Data Kualitatif dengan Skala 5.

\begin{tabular}{ccc}
\hline $\begin{array}{c}\text { Klasifikasi } \\
\text { Data } \\
\text { Kuantitatif }\end{array}$ & $\begin{array}{c}\text { Jumlah Skor } \\
\text { Penilaian }\end{array}$ & $\begin{array}{c}\text { Klasifikasi Data } \\
\text { Kualitatif }\end{array}$ \\
\hline 5 & $235-280$ & Sangat baik \\
4 & $191-235$ & Baik \\
3 & $146-190$ & Cukup \\
2 & $101-145$ & Kurang \\
1 & $56-100$ & Sangat Kurang \\
\hline
\end{tabular}

Berdasarkan tabel hasil skala penilaian dari pakar pendidikan olahraga usia dini, pakar permainan, dan praktisi di atas, maka dapat disimpulkan: (1) permainan Lompat Balok memiliki nilai 274 (235-280) berkategori "sangat baik", (2) permainan Ular dan Katak memiliki nilai 272 (235-280) berkategori "sangat baik, (3) permainan Jalan Kepiting memiliki nilai 275 (235-280) berkategori "sangat baik".

Uji Keefektifan Permainan Tematik pada Uji Coba Skala Besar

Uji keefektifan permainan tematik integratif dapat diketahui dari hasil unjuk kerja anak dalam melakukan permainan yang dinilai 
oleh para praktisi. Uji keefektifan dapat diketahui juga dari hasil dilapangan, yakni ekspresi spontan dari tingkah laku anak seperti anak terlihat gembira, senang, bersorak-sorai, pantang menyerah, ketika berhasil melakukan seperti memadupandakan huruf atau angka, anak-anak berteriak "horee", "yess" (yaaaa), dan bahkan ada beberapa anak bertanya "kapankapan main lagi ya kak?!". Selain itu, uji keefektifan dapat diketahui melalui hasil observasi yang dinilai oleh para pakar dan praktisi dengan demikian, maka dapat disusun klasifikasi nilai yang digunakan sebagai pedoman dalam konversi skor pada semua aspek permainan ke dalam kriteria penilaian sebagai berikut:

Tabel 11. Konversi Data Kuantitif Ke Data kualitatif dengan Skala 5.

\begin{tabular}{ccc}
\hline $\begin{array}{c}\text { Klasifikasi } \\
\text { Data } \\
\text { Kuantitatif }\end{array}$ & $\begin{array}{c}\text { Jumlah Skor } \\
\text { Penilaian }\end{array}$ & $\begin{array}{c}\text { Klasifikasi Data } \\
\text { Kualitatif }\end{array}$ \\
\hline 5 & $172-204$ & Sangat baik \\
4 & $139-171$ & Baik \\
3 & $106-138$ & Cukup \\
2 & $73-105$ & Kurang \\
1 & $40-72$ & Sangat Kurang \\
\hline
\end{tabular}

Tabel uji keefektifan menyimpulkan bahwa: (1) permainan Kupu-kupu Terbang mempunyai jumlah nilai 193, berkategori "sangat baik" (172-204), (2) permainan Lompat Kelinci mempunyai jumlah nilai 194 , berkategori "sangat baik" (172-204), dan (3) permainan Pesawat Terbang mempunyai jumlah nilai 195, berkategori “sangat baik" (172-204).

Berdasarkan penilaian hasil uji keefektifan pada uji coba skala besar pakar pendidikan olahraga usia dini, pakar permainan, dan praktisi, maka dapat disusun klasifikasi nilai yang digunakan sebagai pedoman dalam konversi skor pada semua aspek permainan ke dalam kriteria penilaian sebagai berikut:

Tabel 12. Konversi Data Kuantitif ke Data Kualitatif dengan Skala 5.

\begin{tabular}{ccc}
\hline $\begin{array}{c}\text { Klasifikasi } \\
\text { Data } \\
\text { Kuantitatif }\end{array}$ & $\begin{array}{c}\text { Jumlah Skor } \\
\text { Penilaian }\end{array}$ & $\begin{array}{c}\text { Klasifikasi Data } \\
\text { Kualitatif }\end{array}$ \\
\hline 5 & $136-161$ & Sangat baik \\
4 & $110-135$ & Baik \\
3 & $84-109$ & Cukup \\
2 & $58-83$ & Kurang \\
1 & $32-57$ & Sangat Kurang \\
\hline
\end{tabular}

Tabel uji keefektifan pada uji coba skala besar di atas menyimpulkan bahwa: (1) permainan Lompat Balok mempunyai jumlah nilai 158, berkategori "sangat baik" (136-161), (2) permainan Ular dan Katak mempunyai jumlah nilai 157, berkategori "sangat baik" (136161), dan (3) permainan Jalan Kepiting mempunyai jumlah nilai 155 , berkategori "sangat baik" (136-161), dengan demikian secara keseluruhan dapat disimpulkan bahwa permainan tematik integratif sudah dalam kategori efektif sehingga sudah dapat diajarkan dan diterapkan di pembelajaran mengenal huruf dan angka di taman kanak-kanak.

Hasil Penilaian Pakar Media Terhadap Video dan Buku Panduan Permainan Tematik Integratif pada Uji Coba Skala Besar

Berdasarkan hasil penilaian pakar media terhadap video dan buku panduan pada uji coba skala besar, maka dapat disusun klasifikasi yang akan digunakan sebagai pedoman dalam konversi skor pada semua aspek ke dalam kriteria penilaian permainan tematik integratif, untuk lebih jelas berikut akan disajikan klasifikasi penilaian dalam bentuk tabel:

Tabel 13.Konversi Data Kuantitif Ke Data kualitatif dengan Skala 5.

\begin{tabular}{ccc}
\hline $\begin{array}{c}\text { Klasifikasi } \\
\text { Data } \\
\text { Kuantitatif }\end{array}$ & $\begin{array}{c}\text { Jumlah Skor } \\
\text { Penilaian }\end{array}$ & $\begin{array}{c}\text { Klasifikasi Data } \\
\text { Kualitatif }\end{array}$ \\
\hline 5 & $47-55$ & Sangat baik \\
4 & $38-46$ & Baik \\
3 & $29-37$ & Cukup \\
2 & $19-28$ & Kurang \\
1 & $10-18$ & Sangat Kurang \\
\hline
\end{tabular}

Hasil penilaian pakar media: (1) penilaian terhadap video permainan tematik integratif mempunyai jumlah nilai 48 , berkategori "sangat baik" (47-55), dan (2) penilaian buku permainan tematik integratif mempunyai jumlah nilai 49, berkategori "sangat baik" (4755).

Revisi Produk

\section{Hasil Revisi Validasi Produk}

Hasil revisi dari pakar pendidikan olahraga usia dini, pakar permainan, dan praktisi di uji coba validasi sebagai berikut:

Pertama, revisi dari pakar Pendidikan Olahraga Usia Dini, yaitu (a) semua desain permainan disesuaikan dengan tingkat pencapaian anak taman kanak-kanak, (b) hasil 
penilaian disesuaikan pada prosedur penilaian pada anak taman kanak-kanak, (c) permainan harus mencakup aspek pengembangan fisik/motorik, kognitif, bahasa, sosial/emosional, nilainilai norma dan agama.

Kedua, revisi dari pakar permainan, yaitu (a) spesifikasi lapangan, alat, lama waktu pelaksanaan lebih spesifik, (b) gunakan kurikulum 2013 sebagai acuan pembuatan Rencana Kegiatan Harian (RKH), (c) rumusan tujuan dan indikator disetiap rencana pelaksanaan pembelajaran harus jelas, (d) kriteria penilaian disetiap permainan diperjelas.

Ketiga, revisi dari praktisi, yaitu (a) media yang digunakan dirancang lebih sistematis, (b) di kegiatan akhir permainan sebaiknya anak diberikan hadiah (reward), dan (c) ketika anak menunggu giliran untuk bermain, anak-anak sebaiknya diberikan aktivitas.

\section{Hasil Revisi Uji Coba Skala Kecil Produk}

Revisi yang disarankan oleh pakar pendidikan olahraga usia dini, pakar permainan, dan praktisi sebagai berikut:

Pertama, Revisi dari Pakar Pendidikan Olahraga Usia Dini, yaitu (a) aktivitas Lompat Kelinci, Lompat katak jarak antara kaki dengan paha cukup dengan sudut $\pm 110^{\circ}$, (b) aktivitas sentuh bola jangan terlalu tinggi, diusahakan setiap anak dapat menjangkau/menyentuh setiap bola, (c) balok warna merah direndahkan, karena banyak anak yang masih mengalami kesulitan, cukup 20-30 cm.

Kedua, Revisi dari Pakar, yaitu (a) masih ada anak yang masih mengalami kesulitan dalam melakukan lompat balok, khususnya balok warna merah harus direndahkan lagi + $5 \mathrm{~cm}$, (b) anak yang belum melakukan diberikan aktivitas berupa bernyanyi dan lain-lain, (c) penilaian tingkat pencapaian anak terhadap hasil unjuk kerja diperjelas dan dispesifikkan.

Ketiga, Revisi dari Praktisi, yaitu (a) permainan pesawat terbang anak-anak diberi aksesoris topi pilot, (b) secara keseluruhan permainannya bagus, (c) permainananya menginspiratif, dan (d) sukses buat Asri yaaa...!!!

\section{Hasil Revisi Uji Coba Skala Besar Produk}

Revisi yang disarankan oleh pakar pendidikan olahraga usia dini, pakar permainan, dan praktisi sebagai berikut: Pertama, Revisi dari Pakar Pendidikan Olahraga Usia Dini, yaitu secara keseluruhan permainan sudah berjalan sesuai dengan tingkat pencapaian anak kelompok $\mathrm{B}$, penelitian ini dapat digunakan produksi masal. Kedua, revisi dari pakar permainan adalah permainan sudah berjalan dengan baik, penelitian ini dapat digunakan produksi masal. Ketiga, revisi dari praktisi, yaitu (a) permainanya bagus, (b) walaupun saya sudah tua senang belajar, terima kasih saya dapat belajar banyak dan mendapat pengalaman yang baru, (c) permainanya Dapat menginspirasi untuk membuat permainan edukatif seperti permainan yang dikembangkan ini dan (d) sukses buat mas Asri "good luck".

\section{Simpulan dan Saran}

Simpulan

Penelitian model permainan tematik integratif untuk meningkatkan kebugaran jasmani, mengenal huruf dan angka pada anak taman kanak-kanak menghasilkan enam macam bentuk permainan yakni; (1) permainan Kupukupu Terbang (mengenal huruf), (2) permainan Lompat Kelinci (mengenal angka), (3) permainan Pesawat Terbang (mengenal huruf), (4) permainan Lompat Balok (mengenal angka), (5) permainan Ular dan Katak (mengenal huruf), dan (6) permainan Jalan Kepiting (mengenal angka). Keenam macam permainan tersebut telah menjalani langkah-langkah penelitian dan pengembangan Sugiyono, (2010, pp.409-426) yakni dimulai dari, (1) adanya potensi dan masalah, (2) mengumpulkan informasi, (3) menyusun desain produk, (4) validasi desain, (5) perbaikkan desain, (6) uji coba produk, (7) revisi produk, (8) uji coba pemakaian, (9) revisi produk, dan (10) pembuatan produk masal.

Dari keenam macam permainan tematik integratif di atas berkategori "sangat baik". Dengan demikian untuk sementara dapat diasumsikan bahwa permainan tematik integratif dapat mengajak anak bermain seraya belajar dengan tanpa mengambil hak anak untuk bermain dan tanpa mengabaikan kewajiban anak untuk belajar (pembelajaran dengan pendekatan permainan), model permainan tematik integratif sudah sesuai dengan kurikulum 2013, sehingga dapat mendukung kurikulum 2013, model permainan tematik integratif layak untuk di ajarkan atau diaplikasikan di dalam pembelajaran taman kanak-kanak usia 4-6 tahun pada kelompok B (Nol besar), permainan tematik integratif dapat diajarkan di taman kanak-kanak kelompok A (Nol kecil) dan kelompok bermain, namun disesuaikan dengan tingkat pencapaian perkembangan anak (TPP). 
Saran

Ada beberapa saran pemanfaat produk untuk praktisi taman kanak-kanak dan orangtua yakni sebagai berikut:

Pertama, Model permainan tematik integratif merupakan salah satu bentuk bermain seraya belajar yang bermakna, kebermaknaan permainan tematik integratif ini sangat luas yakni dapat menstimulus pertumbuhan dan perkembangan optimal, memberikan pengalaman gerak, memberikan informasi pengetahuan sesuai dengan tema, menyalurkan aktivitas bermain tanpa mengabaikan kegiatan belajar, dengan demikian disarankan untuk guru taman kanak-kanak dan orangtua untuk mengajarkan permainan tematik integratif. Kedua, Permainan tematik integratif dapat diajarkan di kelompok A dan kelompok bermain, namun disesuaikan dengan tingkat pencapaian perkembangan anak. Ketiga, Tema permainan, media permainan, bentuk pemanasan, bentuk pendinginan, sarana dan prasarana dapat dimodifikasi sesuai dengan keadaan sekolah masing-masing.

\section{Daftar Pustaka}

Athar, G. A. (2011). Pengembangan pembelajaran matematika dengan pendekatan pendidikan matematika realistik (PMR) berbasis budaya cerita rakyat melayu riau pada kelas 3 sekolah dasar. Tesis, tidak dipublikasikan, Universitas Negeri Yogyakarta.

Borg, W.R., \& Gall, M.D. (2007). Educational research: an introduction (8th). New York \& London: Longman.

Condro, R.M. (2009). Meningkatkan kemampuan matematika di sekolah dasar dengan menggunakan pembelajaran sosiokultural. Jurnal Penelitian Ilmu Pendidikan. Volume 3 No. 2 September. ISSN. 1979-9594, pp.166178, Yogyakarta: Fakultas Ilmu Pendidikan Universitas Negeri Yogyakarta.

Davis., et.al. (2009). Early childhood education for sustainability: recommendations for development. International Journal of Early Childhood, Vol. 41, No. 2, 2009.

Elliot, S., \& Davis, J. (2009). Exploring the resistance: an australian perspective on educating for sustainability in early childhood. International Journal of Early Childhood, Vol. 41, No. 2, 2009.

Joyce, B., \& Weil, M. (2004). Models of teaching. Boston: Pearson Education. Inc.

Morgan, P.L., et.al. (2009). Five-year growth trajectories of kindergarten children with learning difficulties in mathematics. Journal of Learning Disabilities, Volume 42 Number 4.

Paiman. (2009). Olahraga dan kebugaran jasmani (physical fitness) pada anak usia dini. Jurnal Cakrawala Pendidikan, November 2009, Th. XXVIII, No. 3.

Praptiningrum, N. (2009). Metode multisensori untuk mengembangkan kemampuan membaca anak disleksia di SD ingklusi. Jurnal Penelitian Ilmu Pendidikan. Volume 2 No. 2 September. ISSN. 1979-9594. pp.179-193, Yogyakarta: Fakultas Ilmu Pendidikan Universitas Negeri Yogyakarta.

Putra, N. (2012). Research and development penelitian dan pengembangan: suatu pengantar. Jakarta: PT Raja Grafindo Persada.

Republik Indonesia. (2003). Undang-undang Republik Indonesia No. 20 tahun 2003, Tentang Sistem Pendidikan Nasional.

Rolina, N. (2010). Model pembelajaran atraktif (atraktive learning) untuk meningkatkan minat belajar siswa taman kanakkanak (TK). Jurnal Penelitian Ilmu Pendidikan. Volume 3 No. 2 September. ISSN. 1979-9594. Hal 135-148, Yogyakarta: Fakultas Ilmu Pendidikan Universitas Negeri Yogyakarta.

Rusijono. (2007). Pengembangan model evaluasi kebijkakan kegiatan belajar membaca di taman kanak-kanak. Jurnal Penelitian dan evaluasi pendidikan. ISSN: $1410-4725$.

Seefeldt, C. (2008). Pendidikan anak usia dini. Jakarta: PT. Indeks. 
Sugiyono. (2010). Prosedur penelitian suatu pendekatan praktek. Jakarta: Rineka Cipta.

Suharjana. (2013). Kebugaran jasmani. Yogyakarta: Jogja Global Media.

Tomoliyus. (2012). Pembuatan alat aktivitas jasmani edukatif, kreatif dan Inovatif berbasis budaya dan lingkungan untuk anak TK. Yogyakarta: Fakultas Ilmu
Keolahragaan Universitas Negeri Yogyakarta.

Trianto. (2011). Desain pengembangan pembelajaran tematik. Jakarta: Kencana Penada Media Group.

Widoyoko, E.P. (2012). Teknik penyusunan instrumen penelitian. Yogyakarta: Pustaka Pelajar. 